\title{
DISCURSO DE RECEPÇÃO DE JOSÉ LUÍS JOBIM NO PEN CLUBE DO BRASIL
}

Há treze anos, foi publicado um livro relatando uma deliciosa conversa entre o músico Tom Jobim e os escritores Antonio Candido, Callado e Houaiss. O livro chamava-se Três Antônios e um Jobim. Hoje, nesta bela cerimônia de posse no PEN Clube, sou tentado a denominar meu breve discurso de recepção de "Três Jobins e um Antonio"; este, o que vos fala, aqueles, as três faces de José Luís Jobim: a do professor, a do administrador e a do escritor, três maneiras diversas de afirmar a mesma excelência.

O professor Jobim talvez não se recorde, mas estive entre os que assistiram ao concurso público de provas e de títulos para professor adjunto em que ele se saiu vitorioso, na Universidade do Estado do Rio de Janeiro (UERJ), em 1994. Há 21 anos tornou-se também professor da Universidade Federal Fluminense (UFF) e, atualmente, é professor titular de Teoria da Literatura na UERJ. A contínua auto-exigência de aperfeiçoamento profissional o fez trilhar todas as etapas do ensino e da pesquisa, tornandose sucessivamente mestre, doutor e pós-doutor em Letras. Sua tese de doutorado teve por tema o livro didático e o ensino de literatura no segundo grau, evidenciando a preocupação de Jobim em refletir sobre as inter-relaçóes entre os diversos segmentos da difusão do saber literário. Tais desdobramentos práticos sáo a tônica das indagaçôes do nosso caro teórico. Pesquisador do $\mathrm{CNPq}$, náo restringe à sala de aula o alcance de suas intervenções no magistério, sendo continuamente requisitado como orientador de dissertaçôes e teses, num total de 22 pesquisas concluídas e aprovadas.

Não se esquiva de contribuir também para o aperfeiçoamento das instituiçôes a que se vincula, daí resultando, paralela a seu trabalho docente, uma notável atuação no campo administrativo. Atualmente, é diretor (eleito pelo voto de todos os segmentos da comunidade) do Instituto de Letras da UERJ e ocupou o cargo, talvez, de maior responsabilidade no âmbito das organizaçôes universitárias de Letras: a presidência da Associação Brasileira de Literatura Comparada, a ABRALIC, a maior do gênero da América Latina, com 1200 associados. Comandada pela tenacidade, competência e entusiasmo de Jobim, a ABRALIC sediou, no Rio de Janeiro, seu X Congresso Internacional, em fins de julho de 2006, com o tema "O local, o regional, o nacional, o inter-nacional, o planetário: lugares dos discursos literários e culturais". O evento congregou mais de 2500 pessoas. Na condição 
de secretário da entidade, pude acompanhar mais de perto a atuação de Jobim, e constatei sua irreprimível vocaçáo de desarmar conflitos e propor alternativas exequíveis em terreno quase sempre minado pelos conflitos de interesse ou solapado por gigantescas vaidades. Jobim era o ponto de equilíbrio, a voz sensata que, em ano de frustrados anseios futebolísticos, controlava a bola no meio-de-campo para, sem egoísmo, passá-la a fim de que um companheiro mais bem colocado fizesse o gol, que, afinal, é o resultado de uma articulaçáo feliz envolvendo o trabalho de uma equipe inteira.

Deixei para o final o registro do terceiro Jobim, o escritor. Ora na autoria ou na organização de livros, ora como colaborador de periódicos nacionais e estrangeiros, Jobim registra mais de uma centena de publicaçóes. No âmbito da reflexão teórico-crítica, é indispensável assinalar as obras Introdução ao Romantismo, 1999; A biblioteca de Machado de Assis, 2001; Formas da teoria, 2003; e Literatura e informática, 2005. A abrangência de temas revela uma sensibilidade simultaneamente atenta à preservaçáo de nosso legado cultural e antenado às transformaçóes tecnológicas que entabulam um profícuo diálogo com o futuro.

Mas, em tão vasta e qualificada produção, prefiro efetuar o resgate de uma faceta injustamente posta em penumbra pelo próprio Jobim. Refiro-me ao poeta, que, em 1980, lançou Panorama do concreto e, em 1987, Ponto final. O primeiro, publicado em ediçáo conjunta com Carlos Augusto Corrêa sob o título Itinerário urbano, foi ganhador do concurso nacional de poesia comemorativo do cinquentenário da Fundação Casa do Estudante do Brasil, e desenvolve, em uma dicção extremamente concisa, um contracanto anti-ufanístico centrado nas mazelas subumanas dos habitantes às margens pouco plácidas da Pauliceia barra-pesadíssima dos anos 70. Outra seria a proposta da obra de 87, que, desde o título - Ponto final - acena para a temática da decomposição, do aniquilamento e da morte, que povoa todo o volume. Jobim convoca autores de várias épocas e latitudes para lhe fornecerem epígrafes, com as quais dialoga em textos, muitos deles, de notável rendimento estético. Paradoxalmente, é no diálogo com as vozes do Outro que a de Jobim se afirma em maior nitidez. Evidencia-se, também, o ganho formal do livro em confronto com a publicação de estreia, seja na prática do soneto, seja na composição de peças que atestam grande domínio de recursos rítmico-rímicos. O viés meditativo é a tônica do volume, como se percebe, por exemplo, nos dísticos decassílabos dedicados a um louco: "Sequer vislumbramos sua paisagem, / nem imaginamos suas imagens. // Mal suportamos essa sua voz / que insiste tanto em lembrar-se de nós: // Evitamos a lembrança que vemos / por causa do louco em nós, que tememos". Na afetuosa 
dedicatória com que fui brindado, José Luís anotou: "este ponto que, espero, é apenas vírgula". De público, cobro a transformação deste sinal, aguardando a vírgula, que abre caminho para novas frases, e o travessão, na demanda de novos diálogos.

Secchin/ Jobim é uma rima. Conhecendo a capacidade do amigo, do escritor, do profissional que hoje ingressa no qualificado quadro de membros desta Casa, e conhecendo igualmente sua inesgotável disposição e operosidade para trabalhar em prol das instituiçóes a que se integra, posso garantir-lhes: além de uma rima, Jobim é uma solução.

Bandeira e José Luís falaram da morte. Em "Consoada”, o poeta pernambucano aludiu à "Indesejada das gentes". Eleito por inteligente unanimidade para o PEN Clube, Jobim revelou-se o "desejado das gentes". Por isso, ao chegar, encontra-nos aqui, para recebê-lo, com a casa limpa e a mesa posta, com cada coisa em seu lugar. Este é um lugar de produção do saber. Este é o seu lugar. Bem-vindo!

Rio de Janeiro, 14 de agosto de 2006.

Antonio Carlos Secchin (UFRJ-Academia Brasileira de Letras) 